\title{
THE PARADOXICAL SUCCESS OF UNCLOS PART XV: A HALF- HEARTED REPLY TO ROSEMARY RAYFUSE
}

\author{
Andrew Serdy*
}

In his reply to Rosemary Rayfuse's article, "The Future of Compulsory Dispute Settlement under the Law of the Sea Convention", Andrew Serdy addresses some of the criticisms that have been levelled at the Part XV dispute resolution provisions of the United Nations Convention on the Law of the Sea (UNCLOS). He concludes that despite being little used, the Part XV provisions remain pivotal to $U N C L O S$ and its related treaties, and if anything are becoming more so.

This contribution will depart less from Rosemary Rayfuse's conclusions than might have been predicted by anyone present at the September 2004 symposium, since the author's brief on that occasion was to exaggerate his differences with her for theatrical effect. Though not confined to the trivial, such differences as do exist are largely questions of degree, to enumerate which would not move the debate on dispute settlement in the law of the sea very far forward. It seems more profitable to concentrate instead on just a handful of observations prompted by the thoughtful Rayfuse article. ${ }^{1}$ It is possible to distil these into just two main propositions: (1) the fact that the machinery of Part XV of the United Nations Convention on the Law of the Sea (UNCLOS) ${ }^{2}$ is rarely invoked is not evidence of the failure of the system, and indeed if anything suggests the opposite; (2) states themselves, far from dismissing Part XV as a failed experiment, have repeatedly shown themselves ready to extend it to other law of the sea treaties and to widen the function of

* School of Law, University of Southampton; PhD candidate, Faculty of Law, Australian National University, Canberra; Visiting Fellow, Faculty of Law, University of Wollongong, New South Wales. The author thanks the organisers of the symposium for their financial assistance towards bringing him to Wellington. He may be contacted at A.L.Serdy@soton.ac.uk.

1 Rosemary Rayfuse "The Future of Compulsory Dispute Settlement under the Law of the Sea Convention" 36 VUWLR 683.

2 United Nations Convention on the Law of the Sea (10 December 1982) 1833 UNTS 3. 
dispute settlement to include perhaps the thorniest problem of all, the question of allocation in quota-limited fisheries.

On the first proposition, admittedly, one of the untidier aspects of the system from the point of view of efficiency, in terms both of maximising return from financial and intellectual capital employed and of creating a cohesive body of law, is that the International Tribunal for the Law of the Sea (ITLOS) as an institution was created on a scale much grander than its narrowly circumscribed compulsory jurisdiction. Endowed with a statute (Annex VI to UNCLOS) and other provisions based on those of the International Court of Justice (ICJ) yet clearly aiming to improve upon them, ${ }^{3}$ and with six more judges than the ICJ, it is anomalous that ITLOS is not the default forum to which a Part XV dispute goes, if the parties do not concur on sending it elsewhere, this role falls to an ad hoc arbitral tribunal formed under Annex VII to UNCLOS. As Rosemary Rayfuse points out, ${ }^{4}$ the vast bulk of ITLOS's workload to date has been in two of the three areas where it has compulsory jurisdiction - under article 290(5) for provisional measures pending the establishment of an ad hoc arbitral tribunal under annex VII or VIII, and article 292 prompt release cases. It would be fair to say that in each of those, albeit after a somewhat shaky start on prompt release, most observers would agree it has acquitted itself tolerably well. The real problem is that the core function of ITLOS, which the drafters assumed would be what kept it busy, was its third source of compulsory jurisdiction, under the deep seabed mining provisions of Part XI. ${ }^{5}$ Since this will bring in private sector litigants, which do not share the reticence of states to settle their disputes

3 For example article 290(6) of UNCLOS plainly stipulates that provisional measures are binding on the parties to a Part XV dispute, something that until the LaGrand case was not clear of interim measures indicated by the ICJ under article 41 of its statute: LaGrand (Germany v United States of America) [2001] ICJ Rep 466, paras 98-109 (ITLOS).

4 Rayfuse, above n 1.

5 See United Nations Convention on the Law of the Sea, above n 2, arts 186-191. It is early in the proposals for regulating deep seabed mining that the first origins of what is not the Seabed Chamber of ITLOS and its specialised jurisdiction are to be found. The Draft United Nations Convention on the International Seabed Area introduced into the Seabed Committee by the United States in 1970 would have created a "Tribunal" as one of the three principal organs of the proposed International Seabed Resource Authority: see Draft United Nations Convention on the International Seabed Area (3 August 1970) A/AC.138/25; art 31. Extensive provisions on the putative tribunal's jurisdiction and competence are found in articles 46 to 60 . The Draft Convention is reproduced in UNGA "Report of the Committee on the Peaceful Uses of the SeaBed and the Ocean Floor Beyond National Jurisdiction" (1970) A/8021, annex V, 130. The authoritative Virginia Commentary argues that these provisions have a different origin and legislative history from the general dispute settlement provisions of Part XV: see Satya N Nandan, Michael W Lodge and Shabtai Rosenne The United Nations Convention on the Law of the Sea 1982: A Commentary (Vol 6, Martinus Nijhoff, New York, 2002) 595. The United States draft is the first source given in particular for the jurisdiction of the Seabed Chamber of ITLOS under article 187 and its power to give advisory opinions (not found in Part XV) in article 191: 609-610 and 642. 
by adjudication, ${ }^{6}$ the drafters are likely eventually to be proved right one day, far off though that day may be. ${ }^{7}$

The drawback of this for most of the law of the sea community - and this includes government lawyers practising in the field, a category into which the author until recently fell - is that it is actual disputes that are the most interesting, and the infrequency of recourse to Part XV is bound to be a little disappointing from a professional perspective. It should be remembered, however, that the government lawyers' job, no less than that of private practitioners, is to keep their client out of court. Invocation of a compulsory dispute settlement clause is, and should be seen as, a last resort. Settling differences by negotiation is the stock in trade of every foreign ministry. For governments to embark on international litigation involves doing two things they are always reluctant to do: one is to deliver the fate of their policy into the hands of a body over which they have no control, ${ }^{8}$ and the other is to admit failure, in this case the failure of their diplomacy to avert the crisis. Thus, satisfying and memorable though the experience of pitting one's wits against one's opponents in arguing a case may be, being called on to do so frequently in the service of a single government would be the sign of a serious problem.

Litigation is a high-risk venture. At best it is a zero-sum game and often the outcome is loselose. The two cases in which Australia was a party to date under Part XV both illustrate this. In the $V o l g a,{ }^{9}$ a prompt release case before ITLOS under article 292, on one hand the eponymous vessel's owners and Russia went to a great deal of trouble and expense, but the nominal success they secured did not reduce the bond to a level they were prepared to pay. ${ }^{10}$ Thus, three years after its capture, the Volga remains in Fremantle. On the other hand, the decision dealt a blow against fisheries law enforcement by striking down the use of good-behaviour bonds. ${ }^{11}$ Although the other case, the

6 See for example Ted L McDorman "Global Ocean Governance and International Adjudicative Dispute Resolution" (2000) 43 Ocean and Coastal Management 255, 269-270 and sources there cited.

7 Even then, however, it is hard to imagine ITLOS ever getting so much work as to generate calls for membership of it to become a full-time occupation, at present only the President is required to live in Hamburg, the site of its seat.

8 Again the analysis of McDorman, above n 6, 270, matches with great accuracy the author's own experiences within officialdom.

9 Volga (Russian Federation v Australia) (2003) 42 ILM 159 (ITLOS).

10 The Australian Fisheries Management Authority set a bond of AUD\$3.3 million for the Volga, of which $\$ 1.9$ million was for the value of the vessel and the remainder was under various other heads, while the owners offered AUD $\$ 500,000$. The bond set by ITLOS was the full value of the vessel, which its owners did not contest. See Volga, above n 9, paras 71-73.

11 ITLOS held by a majority of 19-2 that the bond contemplated by UNCLOS article 73 was purely financial in nature, so that the AUD\$1 million component of the Australian Fisheries Management Authority demand, being to secure the use by the Volga of an acceptable satellite-based vessel-monitoring system if released, made the bond unreasonable. Australian Fisheries Management Authority was thus left unable to 
Southern Bluefin Tuna arbitration, failed on jurisdictional grounds, from the subsequent settlement one could be forgiven for thinking that Australia and New Zealand took the Annex VII tribunal's decision as a defeat on the merits. ${ }^{12}$ Later, however, the received view became that Japan too felt it had lost, for which there are two probable reasons. One is that the tribunal's finding that the substantive obligations of UNCLOS in relation to the species in question had not been discharged or displaced for Japan by its entry into the Convention for the Conservation of Southern Bluefin Tuna seems to have punctured a cherished myth among policymakers. ${ }^{13}$ The other is the consequence of the tribunal's strong hint that, had it come to the opposite conclusion on jurisdiction, it would not have found the case inadmissible merely because it arose out of scientific disagreement ${ }^{14}$ - that such a dispute does not thereby cease to be legal and justiciable. This meant that, in future, legal constraints would have to be taken into account as a matter of course, no doubt an unwelcome intrusion into the hitherto largely self-contained world of the Japanese fisheries authorities.

What good came out of the Southern Bluefin Tuna case, then, came out of the pressure of litigation, first felt through the jurisdiction that could not be avoided - that of ITLOS to prescribe binding provisional measures. Despite the discordant message broadcast by the final settlement, it is easy to imagine how much worse the situation would have been without the ITLOS order and the steps Japan took afterwards in order to stave off a loss on the merits if its objections to jurisdiction

insist, as it had to this point, on the identity of the beneficial owners being disclosed to it. See Volga, above $\mathrm{n} 9$, paras 53 and 80 .

12 In its first year of experimental fishing Japan caught 1464 tonnes of southern bluefin tuna, and in the second year 2198 tonnes. The relief sought by Australia and New Zealand was for Japan to pay this amount back to the stock through reduced future catch. ITLOS's provisional measures order in effect required Japan to pay back the second year's experimental catch over two years. After the first year Japan had paid back 711 tonnes, which was where matters stood at the time the Annex VII tribunal handed down its award. The final settlement allowed Japan to "re-catch" 356 tonnes, half of what it had paid back: see Hon Wilson Tuckey, Minister for Fisheries, Forestry and Conservation "Tuckey Announces End to Southern Bluefin Tuna Dispute with Japan" (29 May 2001) Press Release. But if Australia and New Zealand thought they were splitting the difference with Japan, they were using the wrong yardstick to measure the difference, for the two sides remained in dispute about 3662 tonnes of southern bluefin tuna. If they truly wished to split the difference, Japan would have had to pay back a further 1120 tonnes, for a total of 1831 tonnes. Alternatively, the parties could have drawn a line under this dispute by simply abandoning their claims against each other, leaving the payback at 711 tonnes. The halving of this amount, however, could not avoid carrying implications about how Australia and New Zealand viewed the merits of their dispute; essentially they had written off their claims. The author's impression at the time was that, even before the award, for senior officials the dispute had become a political embarrassment, leaving those dealing directly with Japan after the award with no support for resisting its demands.

13 Southern Bluefin Tuna (New Zealand v Japan, Australia v Japan) (Jurisdiction and Admissability) (4 August 2000) Award of the Arbitral Tribunal; 39 ILM 1359, paras 45-46; Convention for the Conservation of Southern Bluefin Tuna (10 May 1993) 1819 UNTS 360.

14 Southern Bluefin Tuna (Jurisdiction and Admissibility), above n 13, para 65. 
and admissibility failed. In particular, its belated acceptance of a 1500-tonne limit on its experimental catch to ground its argument that the case had become moot. ${ }^{15}$

When considerations such as these are taken into account, it becomes apparent that the fact that there have been only 13 cases in almost as many years does not mean that the Part XV system has failed. Just as the theory of deterrence has it that, in order to preserve peace, one must create a convincing appearance of being prepared to fight war, so too, it is submitted, the best way to achieve widespread compliance with international treaties is through a compulsory dispute settlement mechanism through which failure to comply can be called to account, whether or not actual compensation for any ensuing loss is possible. If so, it follows, the fact that the mechanism is rarely used is a sign of success, not of failure. Supporters of the World Trade Organization often point with pride to its compulsory dispute settlement mechanism and indeed in its first ten years 324 disputes had been brought before its Dispute Settlement Body. ${ }^{16}$ But such a reward is not one of which anyone should be proud - it shows that non-compliance is depressingly frequent, either because the world is not really ready for international trade law or because the substantive law is poorly conceived and drafted, or some combination of the two. In the law of the sea, as set out above the position is rather different, though it is impossible to prove that without Part XV we would actually have more disputes. It is no disrespect to the judges of ITLOS to say that the greatest single service it performs is its mere existence with a record of prompt despatch of its business - which will remain true even in the era of deep seabed mining - and everything above that is a bonus.

Turning to the second proposition, as the major users or potential users of the system, States have shown in a series of negotiations that they retain confidence in Part XV of UNCLOS, by applying it in a number of other treaties. The foremost of these is the United Nations Fish Stocks Agreement, ${ }^{17}$ which not only incorporates Part XV of UNCLOS by reference in its own dispute

15 This too was rejected by the Annex VII tribunal. The tonnage for the experiment was in many ways the least important of the matters dividing the parties; even after Japan's acceptance of this limit the parties remained in disagreement over the minimum design requirements for any experiment if it was to yield useful result as we as over the use to which those results when obtained would be put in assessing the status of the stock - or as the tribunal put it, the "quality as well as the quantity" of the experimental fishing: Southern Bluefish Tuna (Jurisdiction and Admissability), above n 13, paras 45-46.

16 That is, up to the end of 2004. This number is inflated by individual dispute numbers being given to count claims by several WTO members in respect of the same or very similar facts. Moreover, not all of these proceeded to a panel. Even so, the number of panel reports up to 30 June 2005 is still formidable and no less illustrative of the point: 102 by the author's tally, or 96 if related but nominally independent reports handed down on the same day are counted as one. See $<$ http://www.wto.org $>$ (last accessed 10 November 2005).

17 Agreement for the Implementation of the Provisions of the United Nations Convention on the Law of the Sea of 10 December 1982 Relating to the Conservation and Management of Straddling Fish Stocks and Highly Migratory Fish Stocks (4 December 1995) 2167 UNTS 3 [UNFSA]. 
settlement provisions (Part VIII of the Agreement, articles 27 to 32) but also, as among its parties, into every other agreement on fisheries for the relevant stocks. ${ }^{18}$ As not all parties to the latter treaties will necessarily also be parties to the United Nations Fish Stocks Agreement, however, to complete the circle newer constitutive instruments of fisheries commissions themselves incorporate Part XV (via Part VIII of the Fish Stocks Agreement) by reference, whether or not their members are bound by either or both. Two examples here are the Western and Central Pacific Fisheries Convention, ${ }^{19}$ and the South East Atlantic Fisheries Convention. ${ }^{20}$ Another benefit of the institutional side of dispute settlement is the indirect unifying effect it can have on the substantive law. ${ }^{21}$ Thus, in the UNESCO Convention on the Protection of the Underwater Cultural Heritage, ${ }^{22}$ the incorporation of Part XV may yet serve to reassure those among the major maritime states that reject the coastal state's role under the Convention, seeing it as an attempt to shift the jurisdictional balance within UNCLOS in coastal states' favour, that it will not be interpreted this way

Meanwhile, the international fisheries law community must continue its long wait for a case that deals on the merits with the content of the obligation to cooperate. Three chances have come and gone, but none of them can be described as failures of the Part XV system. The first, the dispute between Spain and Canada over the latter's seizure of the Estai on the high seas, was not a failure of the system, because it took place outside it: Canada did not ratify UNCLOS until late 2003. ${ }^{23}$ While the result in the International Court of Justice, ${ }^{24}$ which found that it lacked jurisdiction in the dispute because of Canada's qualification to its optional clause declaration, has not been seriously

18 UNFSA, above n 17, art 30(2).

19 Convention on the Conservation and Management of Highly Migratory Fish Stocks in the Western and Central Pacific Ocean (5 September 2000) 40 ILM 278 [WCPFC], art 31.

20 Convention on the Conservation and Management of Fishery Resources in the South East Atlantic Ocean (20 April 2001) 41 ILM 257, art 24(4).

21 A parallel phenomenon may exist in some federal systems. In Australia there is a single common law not because of any express words to that effect in the Constitution, but because, no matter in what jurisdiction a tort is committed or contract is breached, the final court of appeal is the High Court. In the United States, by contrast, the Supreme Court has no general jurisdiction over such matters, hence there have come to be 51 versions of the common law, including something completely unknown in Australia, Federal common law.

22 Convention on the Protection of the Underwater Cultural Heritage (2 November 2001) 41 ILM 40, art 25(3)-(5).

23 The press release announcing Canada's ratification of UNCLOS in late 2003 cited the rule of law as having been an important factor. Declarations of commitment to the rule of law are normally to be welcomed unreservedly. This one, however, though it would have made sense in 1994 and the years following, by 2003 carried implications less than flattering for how much priority the rule of law was accorded in the previous nine years: Government of Canada "Canada Ratifies United Nations Convention on the Law of the Sea" (6 November 2003) Press Release.

24 Fisheries Jurisdiction (Spain v Canada) (Jurisdiction of the Court) [1998] ICJ Rep 432 (ITLOS). 
questioned, the circumstances in which it came about were nonetheless regrettable. As the optional clause qualification was made with precisely such an incident in mind, ${ }^{25}$ this case represents an important strategic opportunity missed in a situation where the law was ripe for development in the direction of sustainability of fisheries that suited Canada. For, as the second case shows - the Southern Bluefin Tuna case - it is not necessary to win a suit outright in order to benefit from the pressures it exerts on the other side. ${ }^{26}$ Here the system worked at it was supposed to, and it is significant that those who say the Annex VII tribunal's award on jurisdiction was correct feel no compulsion to say that ITLOS erred in prescribing provisional measures; indeed Professor Rosenne, who appeared for Japan, has expressly stated the opposite. ${ }^{27}$ In any event, if Professor Oxman is right, ${ }^{28}$ the effect of the decision will over time be negated by the increase in the number of states that are parties to the United Nations Fish Stocks Agreement, a point made obiter in the award itself. ${ }^{29}$ The last of the three, which formally remains unheard on the ITLOS docket several years after its initiation, was the Swordfish case between Chile and the European Community over Chile's denial of access to its ports to Spanish vessels fishing for this species off its exclusive economic zone. $^{30}$

25 The ICJ noted that the link between the legislation under which the Estai was seized and the excision of disputes of the kind it generated from ICJ jurisdiction was made explicitly in the Canadian Government press release of 10 May 1994 (the day the legislation was introduced into Parliament and the declaration was amended) and in a statement by the Canadian Foreign Minister two days later: Fisheries Jurisdiction (Jurisdiction of the Court), above n 24, para 60.

26 See also on this point Bill Mansfield "The Southern Bluefin Tuna Arbitration: Comments on Professor Barbara Kwiatkowska's Article" (2001) 16 Int'l J Marine and Coastal L 361, 363-364. In subsequent provisional measures cases the litigation has elicited from the respondent states a number of undertakings and assurances that probably would not have otherwise have been given, and which ITLOS placed on record in its orders: see MOX Plant (Ireland v United Kingdom) (2002) 41 ILM 405 (ITLOS), paras 78-80; and Case concerning Land Reclamation by Singapore in and around the Straits of Johor (Malaysia v Singapore) [2003] ITLOS 1, paras 76-81 and 85-88.

27 Shabtai Rosenne Provisional Measures in International Law: The International Court of Justice and the International Tribunal for the Law of the Sea (Oxford University Press, Oxford, 2005) 50-51.

28 Bernard H Oxman "Complimentary Agreements and Compulsory Jurisdiction" (2001) 95 Am J Int'1 L 277, 306-307.

29 Southern Bluefin Tuna (Jurisdiction and Admissability), above n 13, para 71.

30 See generally Marcos A Orellana "The Swordfish Dispute between the EU and Chile at the ITLOS and the WTO" (2002) 71 Nordic J Int'l L 55; and from a partly Australasian perspective Andrew Serdy "See You in Port: Australia and New Zealand as Third Parties in the Dispute between Chile and the European Community over Chile's Denial of Port Access to Spanish Vessels Fishing for Swordfish on the High Seas" (2002) 3 MJIL 79. The latest order continuing the suspension of proceedings was made in December 2003. Under it the clock on the timetable for delivery of memorials in the dispute will restart on 1 January 2006 , unless one of the parties asks for it to be started earlier, or both agree on a further extension of the freeze: Case Concerning the Conservation and Sustainable Exploitation of Swordfish Stocks in the South-Eastern Pacific Ocean (Chile/European Community) (16 December 2003) Order of ITLOS. 
For one final use to which Part XV and its adjuncts can be put, we can turn to disputes about allocation. Whether about fish stocks or rights to or over land or sea, these rarely bring out the best in states, which tend to behave like squabbling children, as indeed the rules on acquiescence and protest encourage them to do. Largely unremarked in the United Nations Fish Stocks Agreement, not in Part VIII but in Part II, is the procedure for interim conservation measures under article 7(5). ${ }^{31}$ This appears to be not an ancillary proceeding but a self-contained one in its own right. We may well not witness much use of this either, but its effect will nonetheless be wholly beneficial. This is so, not because judges are the best people to set catch limits - it may cheerfully be conceded that they are not - but because the mere prospect that this will happen at the instance of any interested party in the absence of agreement is a powerful incentive to compromise. ${ }^{32}$

31 Paragraph 5 reads:

Pending agreement on compatible conservation and management measures, the States concerned, in a spirit of understanding and cooperation, shall make every effort to enter into provisional arrangements of a practical nature. In the event that they are unable to agree on such arrangements, any of the States concerned may, for the purpose of obtaining provisional measures, submit the dispute to a court or tribunal in accordance with the procedures for the settlement of disputes provided for in Part VIII.

32 From a law and economics perspective this is the third-best, proceduralist solution to the tragedy of the commons towards which states have gradually been groping in preference to either of two more comprehensive substantive ones - putting high seas fisheries under a single international institutional owner, or dividing up the quota among states as quasi-owners. While the proceduralist solution is not new (a compulsory arbitration procedure was a feature of the 1958 Convention on the Conservation of the Living Resources of the High Seas), the institutional one is even older: it was suggested by the International Law Commission in 1951 in its "Draft Articles on the Continental Shelf and Related Subjects". Article 2 on "Resources of the Sea" was in the following terms:

Competence should be conferred on a permanent international body ... empowered to make regulations for conservatory measures to be applied by the States whose nationals are engaged in fishing in any particular area where the States concerned are unable to agree among themselves.

Paragraph 3 of the accompanying commentary stated that:

This system [that is, of regulation being left to the States concerned] might prove ineffective if the interested States were unable to reach agreement. The best way of overcoming the difficulty would be to set up a permanent body which, in the event of disagreement, would be competent to submit rules which the States would be required to observe in respect of fishing activities by their nationals in the waters in question. This matter would seem to lie within the general competence of the United Nations Food and Agriculture Organization.

In the International Law Commission's 1953 report the text of draft article 3, as it had become, read:

States shall be under a duty to accept, as binding upon their nationals, any system of regulation of fisheries in any area of the high seas which an international authority, to be created within the framework of the United Nations, shall prescribe as being essential for the purpose of protecting the fishing resources of that area against waste or extermination. Such international authority shall act at the request of any interested State. 
A related innovation is article 20 of the Western and Central Pacific Fisheries Convention, where a review procedure is established for decisions made by qualified majority in the chambered voting system. ${ }^{33}$ A member that has voted against a decision, or was absent at the time of the vote, is bound by the decision 60 days after the decision's adoption unless within the first 30 days it seeks to overturn it on review on limited grounds: its inconsistency with UNCLOS, with the United Nations Fish Stocks Agreement or the Convention itself, or that it unjustifiably discriminates in form or fact against that member. Pending the outcome of the review, the decision is suspended. ${ }^{34}$ If the challenge succeeds, the decision is remitted to the Commission to be modified, amended or revoked in conformity with the findings and recommendations of the review panel..$^{35}$

To conclude, the UNCLOS Part XV dispute settlement mechanism, despite being little used, remains pivotal to UNCLOS and its related treaties, and if anything is becoming more so. Paradoxically, the more disputes it prevents by encouraging compliant behaviour, the less the use to which, on the surface, it appears to be put, with the result that case law is built up only gradually, perhaps frustratingly so. Nonetheless, it is the present author's view that it is still more likely than not to come into its own eventually and earn less cautious approbation than Rosemary Rayfuse among others, is prepared to accord it at present.

References: Conservation of the Living Resources of the High Seas (29 April 1958) 559 UNTS 285; the International Law Commission's 1951 "Draft Articles on the Continental Shelf and Related Subjects" are annexed to: UNGA "Report of the International Law Commission Covering the Work of its Third Session, 16 May-27 July 1951" A/1858; reprinted in Yearbook of the International Law Commission 1951 (vol 2, United Nations, New York, 1957) 123, 143; see also UNGA "Report of the International Law Commission Covering the Work of its Fifth Session, 1 June-14 August 1953" A/2456; reprinted in Yearbook of the International Law Commission 1953 (vol 2, United Nations, New York, 1959) 200, 218.

33 These do not, however, include allocation: WCPFC, above n 19, art 10(4).

34 WCPFC, above n 19, art 20(5) to (7).

35 WCPFC, above n 19, art 20(9). The provision has yet to be invoked; until it is, it will remain unclear who, if anyone, would defend the original decision in the review proceedings. There is no obligation on those states that vote in favour of a challenged decision to do so, nor - though it would seem to be the most efficient way to proceed - is it apparent whether the Secretariat could do so on their behalf without compromising its neutrality. 
